\title{
Growth Performance of Sorghum in Coastal Land with Different Methods of Land Preparation and Plant Spacing
}

\author{
M. Simarmata ${ }^{1 *}$, E. P. Purba ${ }^{1}$, B. W. Simanihuruk ${ }^{1}$, and E. Turmudi ${ }^{1}$ \\ ${ }^{I}$ Department of Crop Production Agricultural Faculty, University of Bengkulu \\ Jalan W.R. Supratman Kandang Limun Bengkulu 38371, Indonesia \\ *Corresponding Author Email: marulak_simarmata@yahoo.com
}

\begin{abstract}
Sorghum (Sorghum bicolor L.) is a cereal plant that has high adaptability on marginal coastal soils. Sorghum can be used as a source of food and feed, while high biomass production has the potential to be used as an industrial raw material for bioethanol production. The objective of this research was to study the combination of land preparation methods with spacing of sorghum in coastal land. The study was done at Muara Bangkahulu District, Bengkulu City. Initial observation found that the research field was sandy soil and dominated by Imperata cylindrica. The experiment was arranged in a split plot design and replicated 3 times. The main plots were land preparation methods that included no- tillage using glyphosate at $1.5 \mathrm{~kg} / \mathrm{ha}$ for land clearing, using paraquat at $1.0 \mathrm{~kg} / \mathrm{ha}$ for land clearing, and two times tillages or conventional tillage. Sub plots were variations of spacing that included $50 \mathrm{~cm} \times 20 \mathrm{~cm}, 60 \mathrm{~cm} \times 20 \mathrm{~cm}$, and $75 \mathrm{~cm} \times 20 \mathrm{~cm}$. The results showed that there was no interaction between land preparation methods with variations of spacing on the growth of sorghum. However, the method of land preparation significantly affected only the leaf area, where the treatment of notillage using glyphosate and paraquat increased leaf areas and was significantly different from conventional tillage. Variation of spacing also affected leaf areas and panicle length where the broadest leaf was 9,064.56 $\mathrm{cm}^{2}$ and the longest panicle was $20.37 \mathrm{~cm}$ observed at $70 \mathrm{~cm}$ x $20 \mathrm{~cm}$ spacing. Thus, no-tillage using glyphosate or paraquat for land clearing are recommended for growing sorghum in coastal lands.
\end{abstract}

Keywords: Coastal land, Conservation tillage, No-tillage, Plant spacing, Sorghum bicolor

\section{INTRODUCTION}

Sorghum (Sorghum bicolor L. Moench) is a foodproducing plant of cereal species [1]. Sorghum originated from Africa but its cultivation has spread widely throughout the world such as Asia, the United States, India, and China $[2,3]$. In Indonesia, sorghum has been known for a long time but its development is relatively slow, perhaps one reason is that the processed sorghum product as a food is not very popular for some Indonesians. Therefore, sorghum is considered as a plant that lacks competitive and comparative values $[4,5]$.

Compared to other cereal crops, sorghum has a broad adaptability, high productivity, relatively little input, resistant to pests and diseases, and tolerant to marginal environmental conditions [6, 7]. Sorghum plants are drought tolerant and able to adapt to sub-optimal land conditions that have high acidity, alkaline and salinity level characteristics, and high level of aluminum content $[1,8,9]$. As a source of carbohydrates, sorghum is ranked fifth amongst cereal crops after wheat, rice, corn, and barley [10]. Sorghum has good nutritional content, it's protein content is even higher than rice and corn [4]. Sorghum seeds are also used as raw material for the animal feed industry, while the stems and leaves are used as feed for ruminants $[5,10]$. In several countries, such as the United States, India and China, sorghum is used as raw material in the bioethanol industry [11 - 13]. From an ecological perspective, sorghum is used as a ground cover crop that has the potential for allelochemicals (bioherbicide) and nematicide (biopesticide) [14 - 16]. The decomposition process of sorghum biomass releases phenolic acids and sorgoleone to the surrounding environment [17, 18], where both compounds are allelochemical compounds that can inhibit weed growth [19]. The decomposition of sorghum biomass can also function as a nematicide because it inhibits the presence of several types of nematodes [16].

In terms of its adaptability, benefits, and potential, sorghum is very suitable to be developed in marginal and unmanaged coastal areas [4,5]. Most of the marginal land ecosystems are dry, sandy and barren land [20]. The management of dry land in coastal areas for crop cultivation can be done after first improving soil marginality by providing organic soil amendments from plant or animal manure $[21,22]$. In previous research, several obstacles 
were found in the development of sorghum on coastal lands, among others, because the land was overgrown with weeds and sorghum was very sensitive to falling. This was due to the texture of the land that was sandy making the sorghum roots unable to strongly hold on to the soil $[22,23]$. Various technical culture methods can be adopted to solve the problem of sorghum cultivation in coastal lands. Modification of tillage with conservation tillage systems without disturbing the surface and texture of the land can strengthen the growth of sorghum roots on sandy soils [24]. Other method is adoption of no-tillage but using herbicides to kill weeds and let the weeds become ground mulch, which can also function as weed-based organic compost [25 - 27]. Two types of herbicides that are often used as tools to kill weed vegetation in no-tillage systems are glyphosate and paraquat $[25,28]$. The herbicide glyphosate (Nphosphonomethyl glycine) is a non-selective and systemic herbicide that kills weeds [29]. After foliar application, the herbicide glyphosate is absorbed and translocated through the phloem tissue to the maristem tissue [30]. The mechanism of action of glyphosate is to inhibit the action of the enzyme EPSP (5-enolpyruvyl shikimate 3-phosphate) which plays a role in the biosynthesis of aromatic amino acids, namely tryptophane, tyrosine, and phenylalanine [29]. The herbicide paraquat (1,1'-dimethyl-4,4'-bipyridinium dichloride) is also a non-selective and contact herbicide, acting rapidly on leaf surfaces [30]. The way it works is by binding to electrons which causes the formation of free radicals which can be oxidized to hydrogen peroxide $\left(\mathrm{H}_{2} \mathrm{O}_{2}\right)$ which is very toxic and damages cell walls and plant tissue [30].

Another obstacle to cultivating sorghum in coastal lands is the high level of plant fall. In order to optimize plant resilience from falling down, it is important to arrange the spacing of the plants so that they can support each other's to stand optimally [31]. Spacing is also an effort to control weeds while increasing plant growth and yield [9]. Various benefits of spacing are uniform plant growth, equal distribution of nutrients, easier maintenance, and suppression of weeds, pests and diseases. Spacing also functions to find out how many seeds are needed at the time of planting adjusted to the area of land [24].

The recommended spacing for sorghum plants is $75 \mathrm{~cm} \times 25 \mathrm{~cm}$ or $75 \mathrm{~cm} \times 20 \mathrm{~cm}$. Sorghum grown in monoculture in one hectare usually contains a 100,000150,000 plant population. An increase in population of more than 150,000 plants per hectare tends to increase yields though it is not that large [32]. The spacing did not have a significant effect on the growth of sorghum, but the spacing had a significant effect on crop yields per plot [33]. Spacing of $50 \mathrm{~cm}$ x $30 \mathrm{~cm}(133,333$ plants/ha) gave higher yields per plot of 4.30 tons/ha compared to the spacing of $75 \mathrm{~cm} \mathrm{x} 25$ $\mathrm{cm}(106,666 \mathrm{plants} / \mathrm{ha})$ of 3.50 tons/ha [31]. The optimum spacing will produce an optimum leaf area index for the formation of maximum dry matter [34]. Tight spacing will increase the competitiveness of plants against weeds because plant canopy inhibits light emission to the land surface, so that weed growth is inhibited [35, 36] and the plant population will increase. An increase in population will reduce the growth and yield of cultivated plants, because there will be competition between the plants themselves. The right spacing really depends on the level of soil fertility, soil cultivation, fertilization and the varieties used [32]. Based on the results of research by Irwan et al. [9], the spacing of $70 \mathrm{x}$ $20 \mathrm{~cm}$ with a combination of granular organic fertilizer 2 tons/ha showed the highest maize plant height.

This research has been carried out with the aim of optimizing the management of dry coastal land through the development of sorghum crops with no-tillage methods integrated with the use of herbicides in land clearing combined with variations in spacing.

\section{METHODOLOGY}

\subsection{Research procedures}

The research was carried out in the coastal area of Beringin Raya Village, Muara Bangkahulu District, Bengkulu City from August, 2018 to January, 2019. The position of the research area is at the coordinates of $3^{0} 45^{\prime} 27.1$ south latitude and $102^{\circ} 15^{\prime} 40.3^{\prime \prime}$ of east longitude, the altitude of 10 meters above the sea level, and the distance from the border of the shoreline is around 100 meters. The land has a sandy soil texture of the regosal type.

The study began with a weed analysis to determine the species of vegetation growing on the experimental land. Ten sample plots sized $50 \mathrm{~cm}$ x $50 \mathrm{~cm}$ each were determined randomly as representations of the entire study area. In each sample plot, weed density and frequency were counted per species, then the Summed Dominance Ratio (SDR) was calculated according to Simarmata et al. [37] (Equation 1).

$$
S D R=\frac{\mathrm{RF}+\mathrm{RD}}{2} x(100 \%) \ldots(\text { Equation } 1)
$$

Where, RF is relative frequency, the ratio of the frequency of a species to the total frequency of all species; RD is relative density, the ratio of the density of a species to the total density of all species.

This study was arranged in a split plot design with two factors and randomized in block. The main-plot consisted of 3 methods of tillage, namely no-tillage and land clearing using glyphosate at $1.5 \mathrm{~kg}$ a.i./ha, no-tillage and land clearing using paraquat-dichloride at $1.0 \mathrm{~kg}$ a.i./ha, and two times of tillage. The sub-plots were spacing for sorghum, which included $50 \mathrm{~cm} \times 20 \mathrm{~cm}, 60 \mathrm{~cm} \times 20 \mathrm{~cm}$, and $75 \mathrm{~cm} \times$ $20 \mathrm{~cm}$. Nine treatment combinations were repeated 3 times as blocks to obtain 27 experimental units. The area of each experimental unit was $2 \mathrm{~m} \times 3 \mathrm{~m}$.

Land preparation was carried out by arranging the experimental plots and separating them with plastic ropes. The distance between the sub-plots was $0.5 \mathrm{~m}$, and the distance between the main plots was one meter. Herbicide application for land clearing used a knapsack sprayer with a spray volume of 400 liters per hectare. Glyphosate herbicide application was carried out 2 weeks earlier, followed by paraquat dichloride application. Calibration was carried out by pumping of spray volume per unit time at 15 psi of sprayer pressure using a flat-van nozzle (1.5 $\mathrm{m}$ of wide range). Weeds that have dried up and died after sprayed with herbicides glyphosate and paraquat applications were 
crushed by grinding wooden blocks. In the $2 x$ tillage plots, the weeds were first cleaned physically, and then the soil was cultivated twice using a hoe. The sorghum seeds of var. B100 that have been tested for germination viability were planted in a hole of 5-cm depth with the spacing as mention previously as a sub-plot factor. The insecticide of Carbofuran granules were added in the planting hole at a recommended dose for preventing the seeds from insects.

Sorghum plant maintenances included irrigation until 14 days after planting, re-planting plants that did not grow, thinning the plants into one plant per planting hole at 7 days after planting, fertilizing, controlling pests, diseases and weeds, and harvesting. Basic fertilizers included Urea, $\mathrm{KCl}$, and SP-36, respectively at 200, 100 , and $150 \mathrm{~kg} / \mathrm{ha}$ were done at the time of planting, except for Urea fertilizer which was done 2 times, namely at planting time and 6 weeks after the planting of $1 / 3$ and $2 / 3$ doses, respectively. Fertilizer was applied in an array of 5-cm apart from the row of plants and then the sorghum seeds were covered with soil. Weed control was carried out chemically at the age of 2 weeks after planting (wap) using the herbicide Calaris ${ }^{\circledR}$ at the dose of 2 liters per hectare. Pests and diseases were controlled by spraying Deltamethrin insecticide and Propinep fungicide at recommended doses.

\subsection{Data collected}

Data collected included 8 sample plants which were selected randomly on each experimental unit. The variables observed in this study consisted of plant height measured from ground level to the tip of the highest leaf using a wooden meter. Measurements were made when the plants were $2,4,6,8$, and 10 wap. The number of leaves was obtained by counting the leaves that had opened perfectly at the age of 2, 4, 6, 8 and 10 wap; flowering age was the number of days from planting until the sorghum plants bloomed more than $50 \%$ at each plot; and leaf area was calculated as Equation 2. The leaf area was measured at the position from the middle of the stem and done when the plant began to flower; length of the panicle was measured from the joint of the panicle to the tip of the sorghum seeds; and data of precifitation were recorded during the study.

$$
L A=(l \times w) x C
$$

Where, LA = leaf area; 1 = leaf length; $\mathrm{w}=$ leaf width; $\mathrm{c}=75 \%$ (correction factor)

\subsection{Data Analysis}

The data observed were analyzed statistically with analysis of variance (ANOVA) and if there was a significant effect on the F-test at 5\% level, the data were further separated with the LSD test at 5\% level. Weed analysis was carried out by calculating the SDR value as Equation 1 to describe the composition of weed dominance per species at the beginning the study.

\section{RESULTS AND DISCUSSION}

The research area has been left for about 6 months and overgrown with weeds. The initial growth of the sorghum plant was slightly stunted due to weather factors. Rainfall and the number of rainy days during the study were $32 \mathrm{~mm}$ with 2 rainy days (September), $164 \mathrm{~mm}$ with 12 rainy days (October), $76 \mathrm{~mm}$ with 4 rainy days (November), and $132 \mathrm{~mm}$ with 8 rainy days (December). Irrigation that was done at the initial growth of the plants stimulated sorghum growth. In the third week after planting, sorghum plants began to be attacked by pests such as grasshoppers that targeted the plant leaves. Other pests that attacked during the growth phase were ants that targeted the stems of plant. Fungi also attacked sorghum plants in the late vegetative phase to the early generative phase. To overcome these pests and diseases, control was carried out using an insecticide of Deltametrin and the fungicide of Propinep at the recommended doses.

Recapitulations of statistical analysis of the data using ANOVA at the 5\% level are presented in Table 1.

Table 1 Recapitulation of F-values from analysis of variance (ANOVA) of growth variables.

\begin{tabular}{|l|c|c|c|}
\hline \multirow{2}{*}{ Growth variables } & \multicolumn{3}{|c|}{ F-Values (5 \%) } \\
\cline { 2 - 4 } & $\begin{array}{c}\text { Tillage } \\
\text { System }\end{array}$ & $\begin{array}{c}\text { Plant } \\
\text { Spacing }\end{array}$ & $\begin{array}{c}\text { Inte- } \\
\text { raction }\end{array}$ \\
\hline Plant height 2 wap & $\begin{array}{c}1339.49 \\
* *\end{array}$ & $0.13^{\text {ns }}$ & $0.14^{\text {ns }}$ \\
\hline Plant height 4 wap & $6.32^{\text {ns }}$ & $0.96^{\text {ns }}$ & $0.06^{\text {ns }}$ \\
\hline Plant height 6 wap & $7.74^{*}$ & $1.52^{\text {ns }}$ & $0.44^{\text {ns }}$ \\
\hline Plant height (8 wap) & $16.30^{*}$ & $0.38^{\text {ns }}$ & $0.38^{\text {ns }}$ \\
\hline Plant height 10 wap & $3.18^{\text {ns }}$ & $0.00^{\text {ns }}$ & $0.29^{\text {ns }}$ \\
\hline $\begin{array}{l}\text { Number of leaves } 2 \\
\text { wap }\end{array}$ & $2.32^{\text {ns }}$ & $0.28^{\text {ns }}$ & $1.12^{\text {ns }}$ \\
\hline $\begin{array}{l}\text { Number of leaves 4 } \\
\text { wap }\end{array}$ & $10,16^{*}$ & $0.12^{\text {ns }}$ & $0.68^{\text {ns }}$ \\
\hline $\begin{array}{l}\text { Number of leaves 6 } \\
\text { wap }\end{array}$ & $24.75^{* *}$ & $0.00^{\text {ns }}$ & $0.82^{\text {ns }}$ \\
\hline $\begin{array}{l}\text { Number of leaves } 8 \\
\text { wap }\end{array}$ & $6.36^{\text {ns }}$ & $0.02^{\text {ns }}$ & $1.08^{\text {ns }}$ \\
\hline $\begin{array}{l}\text { Number of leaves } 10 \\
\text { wap }\end{array}$ & $10.22^{*}$ & $0.00^{\text {ns }}$ & $0.65^{\text {ns }}$ \\
\hline Leaf area & $3.06^{\text {ns }}$ & $0.89^{\text {ns }}$ & $0.85^{\text {ns }}$ \\
\hline Length of panicle & $1.30^{\text {ns }}$ & $4.86^{*}$ & $0.51^{\text {ns }}$ \\
\hline Age of flowering & $1.00^{\text {ns }}$ & $0.00^{\text {ns }}$ & $0.00^{\text {ns }}$ \\
\hline F table (5\%) & 6.94 & 3.88 & 3.25 \\
\hline
\end{tabular}

* = influenced significantly, ns = none significant, wap = week after planting. 
There was no significant interaction between tillage methods and spacing on all observed variables. These circumstances were presumably because the research area was a coastal area which contained a lot of sand, neither tillage nor notillage was different. The land has not been used used for 6 months, so the nutrients were available and there was no competition between sorghum plants even though the spacing was different $[33,34]$. Irwan et al. [9] stated that a good spacing really depends on the level of soil fertility, soil cultivation, fertilization, and the varieties used.

The results of the analysis of variance showed that modification of tillage techniques had a significant effect on plant height at 2, 6, and 8 wap. The tillage methods also had a significant effect on the number of leaves at 4,6 , and 10 wap. These circumstances were thought to be due to environmental factors, such as the temperature of the 2 times of soil tillage which was higher than no-tillage, and the humidity of the 2 times of tillages which was lower than notillage. On the other hand, plant spacing showed a significant effect on the panicle length of sorghum.

\subsection{Weed Analysis}

There were 13 weed species that found in the research area. Axonopus compressus was the most dominant weed in the experimental area with an SDR value of 34.69\%, followed by Echinochloa colona, Ageratum conyzoides, Elecine indica, and Cyperus rotundus with SDRs of 9.5, 9.31, 8.56, and $7.64 \%$. The weed assessment and analysis results are presented in Table 2. Axonopus compressus weeds appear at 8 out of 10 observation points. Axonopus compressus with local named Rumput Pahitan belongs to the Poaceae family. These weeds reproduce sexually and vegetatively by seeds and stolons, respectively. Weed of Axonopus compressus can grow in tropical and sub-tropical areas. It also grows well in marginal lands that are dry, sunny and slightly humid areas.

\subsection{Effect of tillage methods on sorghum growth}

The growth of the sorghum plant height increased when the age of plant increased. The highest increase due to tillage techniques occurred when the sorghum plants were at the age of 6 to 8 wap which was $74.24 \mathrm{~cm}$ with treatment of two times tillage. The lowest increase in plant height due to the treatment of tillage techniques occurred when the sorghum plants were at the age of 8 to 10 wap which was $48.6 \mathrm{~cm}$ with no-tillage and application of paraquat dichloride at $1.0 \mathrm{~kg} / \mathrm{ha}$. The effect of tillage methods on sorghum height from the age of 2 to 10 wap is presented in Figure 1a.

The highest growth of sorghum occured when the plants were about 49 days after planting. Growth point differentiation takes place at this stage. Absorption of nutrients was as fast as plant growth, so the need for nutrients and water was also quite high. The time taken from planting to differentiation of growing points generally takes up onethird of the plant life [35].

Tabel 2 Initial weed assessment on the research field.

\begin{tabular}{|l|c|c|c|c|c|}
\hline \multicolumn{1}{|c|}{ Weed species } & $\begin{array}{c}\text { Frequency } \\
\text { (times) }\end{array}$ & $\begin{array}{c}\text { Relative } \\
\text { Frequency }\end{array}$ & $\begin{array}{c}\text { Density } \\
\text { (inds./m })^{2}\end{array}$ & $\begin{array}{c}\text { Relatif } \\
\text { Density }\end{array}$ & $\begin{array}{c}\text { Summed } \\
\text { Dominance } \\
\text { Ratio (\%) }\end{array}$ \\
\hline 1. Axonopus compressus & 8 & 0.15 & 696 & 0.54 & 34.69 \\
\hline 2. Echinochloa colona. & 5 & 0.10 & 121 & 0.09 & 9.50 \\
\hline 3. Ageratum conyzoides & 5 & 0.10 & 116 & 0.09 & 9.31 \\
\hline 4. Cyperus rotundus & 5 & 0.10 & 73 & 0.06 & 7.64 \\
\hline 5. Eleusine indica & 6 & 0.12 & 72 & 0.06 & 8.56 \\
\hline 6. Asystasia gangetica & 4 & 0.08 & 43 & 0.03 & 5.51 \\
\hline 7. Ischaemum rugosum & 4 & 0.08 & 39 & 0.03 & 5.36 \\
\hline 8. Imperata cylindrica & 4 & 0.08 & 35 & 0.03 & 5.20 \\
\hline 9. Kyllinga brevifolia & 3 & 0.06 & 28 & 0.02 & 3.97 \\
\hline 10. Crassocephalum \\
crepidiodies & 3 & 0.06 & 28 & 0.02 & 3.97 \\
\hline 11. Oxalis barrelieri & 2 & 0.04 & 19 & 0.01 & 2.66 \\
\hline 12. Phyllantus niruri & 2 & 0.04 & 15 & 0.01 & 2.50 \\
\hline 13. Spigelia anthelma & 1 & 0.02 & 4 & 0.00 & 1.12 \\
\hline Total & 52 & 1.00 & 1289 & 1.00 & 100 \\
\hline
\end{tabular}

$\mathrm{F}=$ frequency, $\mathrm{RF}=$ relative frequency, $\mathrm{D}=$ density, $\mathrm{RD}=$ relative density, $\mathrm{SDR}=[($ relative frequency + relative density $)$ : 2] $\times 100 \%$, inds. = individual. 
(1a)

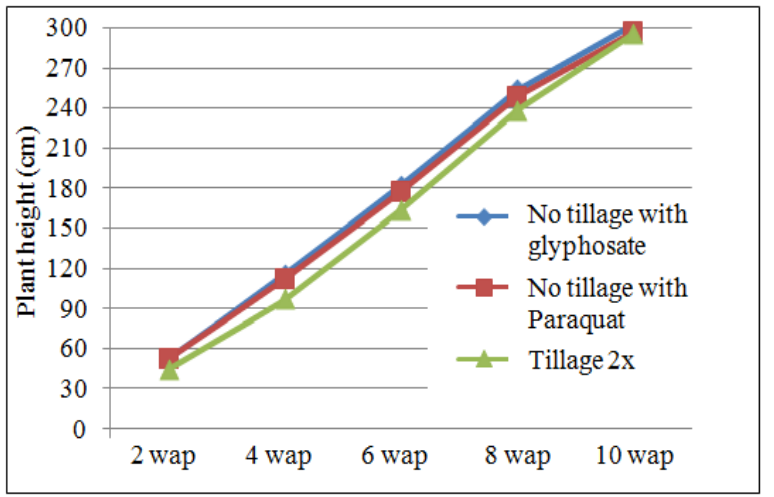

(1b)

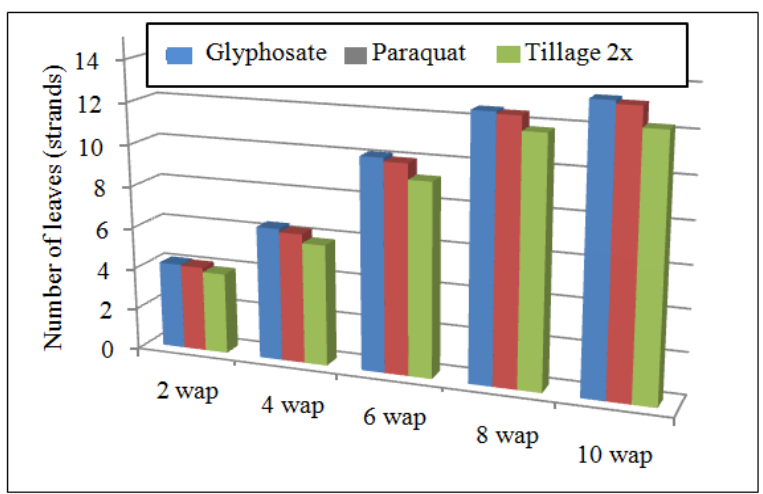

Figure 1 The effect of land preparation methods on plant height (1a) and number of leaves (1b) of sorghum from 2 to 10 weeks after planting (wap)

The no-tillage treatment with the application of glyphosate at $1.5 \mathrm{~kg} / \mathrm{ha}$ resulted in the same plant height as the no-tillage treatment with the application of paraquat dichloride $1.0 \mathrm{~kg} / \mathrm{ha}$. Plant height on those two treatments was higher than the $2 \mathrm{x}$ tillage treatment when they were observed at 2, 4, 6, and 8 wap. These circumstances were presumably because dry coastal lands increased the temperature thereby accelerating water loss, due to $2 \mathrm{x}$ tillage treatment. Intensive tillage in the dry season will accelerate groundwater loss through evaporation [23, 25]. In the 10 wap observation, the average height of the sorghum plants in the three tillage techniques produced the same height. This situation was presumably because the sorghum plants have adapted well under $2 \mathrm{x}$ tillages.

The number of leaves increased when the age of the sorghum plant increased. The highest increase in leaf number due to tillage methods occurred when the sorghum plants were at age 4 to 6 wap which had an average of 3.75 leaves with the no-tillage treatment with glyphosate. The lowest increase in leaf number due to tillage techniques occurred when the sorghum plants were age 8 to 10 wap which had an average of 0.49 strands with $2 x$ tillage treatment. The increase in the leaf number of sorghum at the age of 2 to 10 wap due to tillage techniques is presented in Figure $\mathbf{1 b}$.

Observations at 2 wap showed that the average number of leaves of sorghum plants in the three tillage techniques produced the same height. No-tillage treatment with the application of glyphosate at $1.5 \mathrm{~kg} / \mathrm{ha}$ resulted in the same plant height as no-tillage treatment with the application of paraquat dichloride $1 \mathrm{~kg} / \mathrm{ha}$, but higher than $2 \mathrm{x}$ tillage treatment at the age of $4,6,8$, and 10 wap.

Perfect soil cultivation ( $2 \mathrm{x}$ tillages) has a different effect on the number of leaves of the sorghum at the age of $4,6,8$, and 10 weeks. The average number of leaves of sorghum plants under $2 x$ tillages was lower than that of notillage. Sorghum growth on $2 x$ tillages was inhibited because the soil easily loss water, the soil temperature increased and the humidity decreased. The effect of $2 x$ tillages on the variable leaf area, panicle length and flowering age of sorghum is presented in Table 3 .
Soil cultivation methods had no significant effect on the leaf area of sorghum plants. This was presumably because the research area had a sandy texture and was also supported by good sorghum adaptability, so the sorghum plants could grow well even though the soil was not cultivated (no-tillage). Sorghum is tolerant to drought, can produce on marginal land, and is relatively resistant to pests or diseases [4]. The number and size of the leaves is influenced by plant genetics and the environment in which the plant grows [6].

Table 3 The effect of tillage methods on growth variables.

\begin{tabular}{|l|c|c|c|}
\hline Tillage system & $\begin{array}{c}\text { Leaf } \\
\text { area } \\
\left(\mathrm{cm}^{2}\right)\end{array}$ & $\begin{array}{c}\text { Length of } \\
\text { pannicle } \\
(\mathrm{cm})\end{array}$ & $\begin{array}{c}\text { Flowering } \\
\text { age } \\
\text { (days after } \\
\text { planting })\end{array}$ \\
\hline $\begin{array}{l}\text { No-tillage with } \\
\text { glyphosat }\end{array}$ & 8914.87 & 19.80 & 65 \\
\hline $\begin{array}{l}\text { No-tillage with } \\
\text { paraquat }\end{array}$ & 8961.20 & 19.52 & 65 \\
\hline Tillage 2x & 8377.32 & 20.26 & 67 \\
\hline
\end{tabular}

Sorghum plants in this research had a lower average panicle length compared to the description of the B100 variety. The length of sorghum panicles did not differ in all tillage treatments. This was thought to be because the length of the panicles is a genetic factor. According to Khairunnisa et al [27], panicle length is influenced by genetic factors of a variety and the adaptability of the variety to the environment in which the plant grows. The average of flowering age of sorghum was lower than the description for the B-100 variety, this is presumably due to higher temperatures and sunlight in coastal areas.

\subsection{Effect of plant spacing on sorghum growth}

Plant height increased when the age of sorghum plants increased. The highest increase in plant height due to 
(2a)

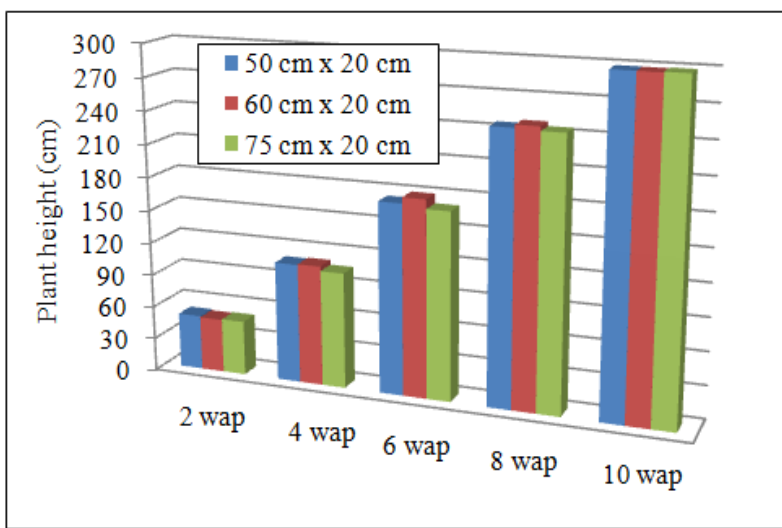

(2b)

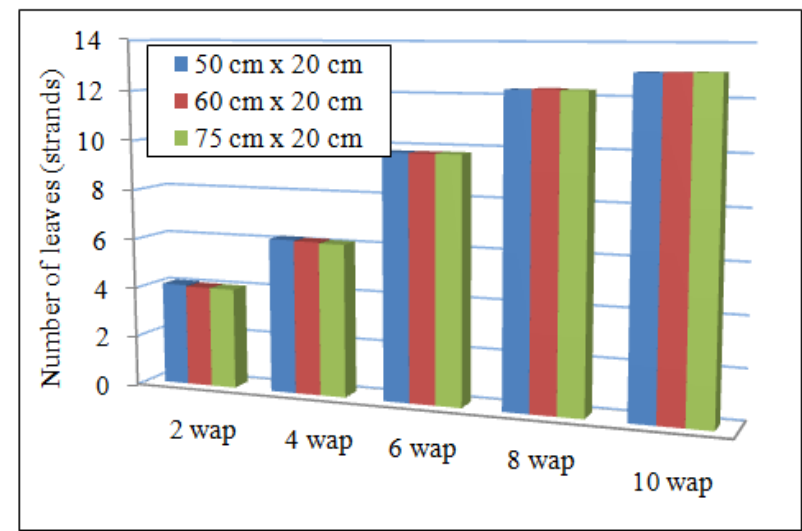

Figure 2 The effect of spacing on plant height (2a) and number of leaves (2b) of sorghum from 2 to 10 weeks after planting (wap)

variations in spacing occurred when the sorghum plants were at age 6 to 8 wap, which was $74.49 \mathrm{~cm}$ with a spacing of 75 $\mathrm{cm} \times 20 \mathrm{~cm}$. The lowest increase in plant height due to variations in spacing occurred when the sorghum plants were at age 8 to 10 wap, amounting to $49.69 \mathrm{~cm}$ at spacing of 60 $\mathrm{cm} \times 20 \mathrm{~cm}$. The growth of the sorghum plant height at the age of 2 to 10 weeks after planting, due to variations in the spacing is presented in Figure 2a.

Observation of plant height 2, 4, 6, 8, and 10 wap showed the same average in all spacing treatments. This was suspected because the spacing of $50 \mathrm{~cm} \times 20 \mathrm{~cm}, 60 \mathrm{~cm} \times 20$ $\mathrm{cm}$, and $75 \mathrm{~cm} \times 20 \mathrm{~cm}$ were still suitable for sorghum. It was recommended that a spacing of $75 \mathrm{~cm} \times 20 \mathrm{~cm}$ is suitable for sorghum [31]. It is assumed that the spacing does not affect plant growth, as long as nutrients and growing space are still available. A good spacing really depends on the level of soil fertility, soil cultivation, fertilization, and the varieties used [9].

The number of leaves increased when the age of the sorghum plant increased. The highest increase in the number of leaves due to variations in the spacing occurred when the sorghum plants were at age 4 to 6 wap, with an average of 3.68 leaves with a spacing of $75 \mathrm{~cm} \times 20 \mathrm{~cm}$. The lowest increase in the number of leaves due to tillage techniques occurred when the sorghum plants were at age 8 to 10 wap, with an average of 0.65 strands at a spacing of $60 \mathrm{~cm} \times 20$ $\mathrm{cm}$. The increase in the number of leaves of sorghum at the age of 2 to 10 wap, due to variations in the spacing is presented in Figure 2b.

Table 4 described the variation in spacing had no significant effect on leaf area and flowering age of sorghum plants. Sorghum planted at a spacing of $50 \mathrm{~cm} \times 20 \mathrm{~cm}, 60$ $\mathrm{cm} \times 20 \mathrm{~cm}$, and $75 \mathrm{~cm} \times 20 \mathrm{~cm}$ produced a lower panicle length compared to the description of the B-100 variety. The spacing of $75 \mathrm{~cm} \times 20 \mathrm{~cm}$ resulted in the longest panicle length which was $20.37 \mathrm{~cm}$. It was indicated that the panicle length of the sorghum plant with a spacing of $60 \mathrm{~cm} \times 20 \mathrm{~cm}$ was higher than that with a spacing of $50 \mathrm{~cm} \times 20 \mathrm{~cm}$. This is presumably because the sorghum planted at a more tenuous distance with a lower population, provided
Table 4 The effect of plant spacing on growth variables of sorghum.

\begin{tabular}{|c|c|c|c|}
\hline $\begin{array}{c}\text { Plant } \\
\text { spacing }\end{array}$ & $\begin{array}{c}\text { Leaf area } \\
\left(\mathrm{cm}^{2}\right)\end{array}$ & $\begin{array}{c}\text { Length of } \\
\text { panicles } \\
(\mathrm{cm})\end{array}$ & $\begin{array}{c}\text { Flowering } \\
\text { time } \\
(\text { days })\end{array}$ \\
\hline $50 \mathrm{~cm} \times 20 \mathrm{~cm}$ & $8,464.72$ & $19.42 \mathrm{~b}$ & 65.67 \\
\hline $60 \mathrm{~cm} \times 20 \mathrm{~cm}$ & $8,724.12$ & $19.79 \mathrm{ab}$ & 65.67 \\
\hline $75 \mathrm{~cm} \times 20 \mathrm{~cm}$ & $9,064.56$ & $20.37 \mathrm{a}$ & 65.67 \\
\hline
\end{tabular}

Numbers followed by the same letter in a column are not significantly different by LSD test at $5 \%$

opportunities for plants to grow more freely, absorb more nutrients and increase plant growth and yield. A wider spacing, the canopy cover area was proportional to the area of land shaded so that the energy obtained is greater to increase vegetative growth [32].

Sorghum planted at different spacing took the same time of 65.67 days to flower. The spacing had no significant effect on the flowering age of sorghum plants. The same situation also occurred in the research by Puspitasari et al. [31] that the number of sorghum flowers planted at a distance of $60 \mathrm{~cm} \times 25 \mathrm{~cm}$ and $70 \mathrm{~cm} \times 20 \mathrm{~cm}$ was not significantly different. The flowering age of sorghum plants is thought to be more influenced by environmental conditions.

\section{CONCLUSION}

The research concluded that there was no interaction between tillage methods and plant spacing on the growth of sorghum in coastal lands. The use of glyphosate for land clearing in no-tillage technique is an appropriate method for cultivating sorghum in coastal lands. Spacing did not affect the growth of sorghum in coastal land, but plant spacing of $75 \mathrm{~cm} \times 20 \mathrm{~cm}$ produced the longest panicle of sorghum of $20.37 \mathrm{~cm}$. 


\section{ACKNOWLEDGMENTS}

The authors would like to thank all helper in the field for their hard work to make this research possible. Our appreciations go to the Dean of Agricultural Faculty, University of Bengkulu for all the supports during the research and completing this manuscript.

\section{REFERENCES}

[1] J. A. Dahlberg, 'Classification and Characterization of Sorghum. In: W.A. Smith, R.A. Frederiksen (eds.). Sorghum: Origin, History, Technology, and Production', John Wiley \& Sons Inc., New York, 2000.

[2] J. A. Mann, C.T. Kimber and F. R. Miller, 'The origin and early cultivation of sorghums in Africa', Texas Agric. Exp. Stn. Bull., pp. 1454, 1983.

[3] N. I. Vavilov, 'Origin and Geography of Cultivated Plants (English Translation)', Cambridge University Press., Cambridge, UK, 1992.

[4] M. P. Sirappa, 'Prospek pengembangan sorgum di Indonesia sebagai komoditas alternatif untuk pangan, pakan, dan industri', Jurnal Litbang Pertanian, vol. 22, no. 4, pp. 133-140, 2003.

[5] H. Subagio and M. Aqil, 'Pengembangan Produksi Sorgum di Indonesia', Seminar Nasional Inovasi Teknologi Pertanian, pp. 199-213, 2013.

[6] L. R. House, 'A Guide to Sorghum Breeding. International Crops Research Institute for SemiArid Tropics', Andhra Pradesh, India, 1985.

[7] FAO, 'Sorghum bicolor (L.) Moench. In Grassland Species Profile Database', 2015. [Online]. Available: http://ww.fao.org/ag/agp/agpc.doc/ gbase/data/pf00319.

[8] J. Berenji, 'Perspective of Sorghum in Europe', JACS, vol. 1905, pp. 332-338, 2004. Doi: https://doi.org/10.1111/j.1439-037X.2004.00102.

[9] A. W. Irwan, A. Wahyudin, R. Susilawati, T. Nurmala, 'Interaksi jarak tanam dan jenis pupuk kandang terhadap komponen hasil dan kadar tepung Sorghum (Sorghum bicolor L. Moench) pada Inseptisol di Jatinangor', Jurnal Kultivasi, vol. 4, no. 2, pp. 128-136, 2005.

[10] J. A. Dahlberg, E. Wolfrum, B. Bean and L. Rooney, 'Compositional and agronomic evaluation of sorghum biomass as a potential feedstock for renewable fuels', Journal of Biobased Materials and Bioenergy, vol. 5, no. 4, pp. 507-513, 2011, doi: http://dx.doi.org/ $10.1166 / \mathrm{jbmb}$.

[11] S. Prasad, A. Singh, N. Jain and H.C. Hoshi, 'Ethanol production from sweet sorghum syrup for utilisation as automotive fuel in India', Energy Fuel, vol. 21, pp. 2415-2420, 2007, doi: https://doi.org/10.1021/ef060328z

[12] C. E. Shoemaker and D. I. Bransby, 'The Role of Sorghum as a Bioenergy Feedstock. In: R. Braun, D. Karlen, and D. Johnson (Eds)', Proc. of the Sustainable Feedstocks for Advance Biofuels Workshop, Atlanta, GA, pp. 149-159, 2010.

[13] M. B. Pabendon, M. Aqil and S. Masud, 'Kajian sumber bahan bakar nabati berbasis sorgum manis', Iptek Tanaman Pangan, vol. 2, no. 7, pp. 123-129, 2012.

[14] A. R. Putnam, J. Defrank and J. P. Barnes, 'Exploitation of allelopathy for weed control in annual and perennial cropping systems', J. Chem. Ecol., vol. 9, pp. 1001-1010, 1983, doi: https://doi.org/10.1007/BF00982207

[15] I. Alsaadawi and F. E. Dayan, 'Potentials and prospects of sorghum allelopathy in agroecosystems', Allelopathy J., vol. 24, pp. 255270, 2009

[16] K. Dover, K., H. Wang, and R. McSorley, 'Nematode Management Using Sorghum and Its Relatives', IFAS Extension, University of Florida, 2014.

[17] C. M. Roth, J. P. Shroyer, and G. M. Paulsen, 'Allelopathy of sorghum on wheat under several tillage system', Agron. J., vol. 92, pp. 855-860, 2000, doi: https://doi.org/10.2134/agronj.

[18] O. J. Won, M. R. Uddin, K. W. Park, J. Y. Pyon, and S. U. Park, 'Phenolic compounds in sorghum leaf extracts and their effects on weed control', Allelopathy Journal, vol. 31, no. 1 pp. 147-156, 2013.

[19] Z. A. Cheema and A. Khaliq, 'Use of sorghum allelopathic properties to control weeds in irrigate wheat in a semi arid region of Punjab', Agriculture, Ecosystems and Environment, vol. 79, pp. 105-112, 2000, doi:10.1016/S01678809(99)00140-1

[20] S. Gunadi, 'Teknologi Pemanfaatan Lahan Marginal Kawasan Pesisir', Jurnal Teknologi Lingkungan, vol. 3, no. 3, pp.: 232-236, 2002.

[21] T. Beatly, D. J. Bower and A. K. Schwab, 'An Introduction to Coastal Zone Management', Island Press, Washington, DC. 2002.

[22] M. Simarmata, M. F. Barchia and S. N. Simatupang, 'Prospect for Growing Sorghum (Sorghum bicolor L. Moench) at Marginal Dry Land in Coastal Area Retrieved with Organic Soil Amendments', AJCS vol. 9, no. 4, pp. 118-124, 2017, doi: 10.3923/ajcs.2017.118.124

[23] M. H. Rashid, S. Nasrin, and D. Mahalder, 'Zero tilled dibbled sunflower enables planting earlier and harvest more in the coastal saline area of Bangladesh', IJESD, vol. 5, no. 3, pp. 260-264, 2014, doi: 10.7763/IJESD.2014.V5.488. 
[24] G.B. Triplett and W. A. Dick, 'No-Tillage Crop Production: A Revolution in Agriculture', Agron. J., vol. 100, no. 3, pp. 153-165, 2008, doi: 10.2134/agronj2007.0005c.

[25] M. Utomo, 'Teknologi terapan yang efektif dan efisien melalui sistem tapa olah tanah berkelanjutan untuk tanaman jagung di lahan kering. Makalah Disampaikan Pada Pertemuan Upaya Khusus Pengembangan Jagung Hibrida. Dinas Pertanian Tanaman Pangan', Ujung Pandang, 1997.

[26] R. Derpsch, T. Friedrich, A. Kassam and L. Hongwen, 'Current status of adoption of no-till farming in the world and some of its benefits', IJABE, vol. 3, no. 1, pp. 1-25, 2010, doi: 10.3965/j.issn.1934-6344.2010.01.0-0.

[27] Khairunnisa, R. R. Lahay, T. Irmansyah, 'Respons Pertumbuhan dan Produksi Tanaman Sorgum (Sorghum bicolor (L.) Moench terhadap Pemberian Mulsa dan Berbagai Metode Olah Tanah', Jurnal Online Agroekoteknologi, vol. 3, no. 1, pp. 359-366, 2015.

[28] Adnan, 'Aplikasi Beberapa Dosis Herbisida Glifosat dan Paraquat pada Sistem Tanpa Olah Tanah (TOT) serta Pengaruhnya terhadap Sifat Kimia Tanah, Karakteristik Gulma dan Hasil Kedelai', J Agrista, vol. 16, no. 3, pp. 135-145, 2012.

[29] S. O. Duke and S. B. Powles, 'Mini review glyphosate: a once-in-a-century herbicide', Pest. Manag. Sci., vol. 64, pp. 319-325, 2008, doi: $10.1002 /$ ps. 1518

[30] W. K. Vencill, K. Armbrust., H. G. Hancock., D. Johnson., G. McDonald., D. Kinter., F. Lichtner., H. McLean., J. Reynolds., D. Rushing., S. Senseman and D. Wauchope, 'Herbicide handbook. 8th ed.', Weed Science Society of America, Lawrence, KS, 2002.

[31] G. Puspitasari, K. Dody and W. Sriyanto, 'Pertumbuhan Dan Hasil Sorgum Manis (Sorghum Bicolor L. Moench) Tanam Baru Dan Ratoon Pada Jarak Tanam Berbeda', J. Vegetalika, vol. 1, no. 4, pp. 11-17, 2012.

[32] A. May, V. F. Souza, G. A. Gravina and P. G. Fernandes, 'Plant population and row spacing on biomass sorghum yield performance', Ciencia Rural, vol. 46, no. 3, pp. 434-439, 2015.

[33] M. R. Gondal, A. Hussain, S. Yasin, M. Musa, and H. S. Rehman, 'Effect of seed rate and row spacing on grain yield of sorghum', SAARC J. Agri, vol. 15, no. 2, pp. 81-91, 2017, doi: https://doi.org/ 10.3329/sja.v15i2.35154.

[34] T. Dejen, B. Woldu, F. Tegegn and G. Adugna, 'Determination of optimum spatial arrangement and plant population in sesame sorghum intercropping', IJDR., vol. 9, no. 08, pp. 2919229196, 2019.

[35] R. J. K. Myers, R. J. K. and M. A. Foale, 'Row spacing and population density in grain sorghum A simple analysis', Field Crops Research, vol. 4, pp. 147-154, 1981, doi: https://doi.org/10.1016/ 0378-4290(81)90064-2.

[36] C. J. Fernandez, D. D. Fromme, W. J. Grichar, 'Grain Sorghum Response to Row Spacing and Plant Populations in the Texas Coastal Bend Region', International Journal of Agronomy, pp. 1-6, 2012, doi: https://doi.org/10.1155/2012/ 238634

[37] M. Simarmata, Sitanggang, C. D. and Djamilah, 'The Shifting of Weed Compositions and Biomass Production in Sweet Corn Field Treated with Organic Composts and Chemical Weed Controls', J. Agrivita vol. 37, pp. 226-236, 2015, doi: 10.17503/Agrivita-2015-37-3-p226-236. 